\title{
New Synthetic Routes toward Enantiopure Nitrogen Donor Ligands
}

\author{
Xavier Sala,$^{\dagger}$ Anna M. Rodríguez, ${ }^{\dagger}$ Montserrat Rodríguez,,$^{*, \dagger}$ Isabel Romero, ${ }^{\dagger}$ \\ Teodor Parella, ${ }^{\ddagger}$ Alexander von Zelewsky, ${ }^{*, \S}$ Antoni Llobet, ${ }^{*, \neq, \|}$ and Jordi Benet-Buchholz" \\ Departament de Química, Universitat de Girona, Campus Montilivi s /n, E-17071 Girona, Spain, \\ Departament de Química, Universitat Autònoma de Barcelona, Cerdanyola del Vallès, E-08193 Barcelona, \\ Spain, Department of Chemistry, University of Fribourg, Pérolles, 1700-Fribourg, Switzerland, and Institut \\ Català d'Investigació Química (ICIQ), Avgda. Països Catalans 16, E-43007 Tarragona, Spain
}

montse.rodriguez@udg.es; antoni.llobet@iciq.es; alexander.vonzelewsky@unifr.ch

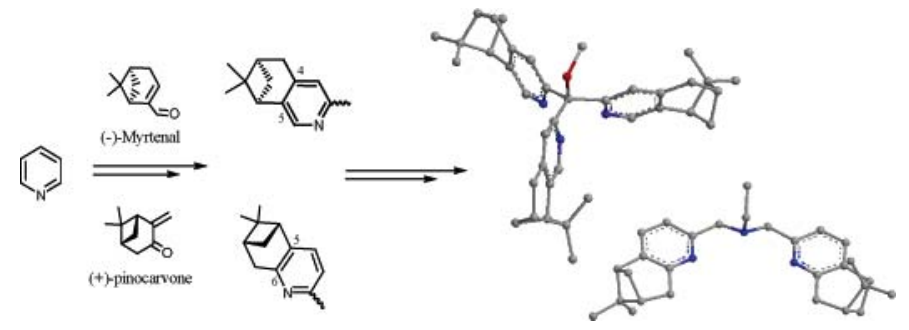

New polypyridylic chiral ligands, having either $C_{3}$ or lower symmetry, have been prepared via a de novo construction of the pyridine nucleus by means of Kröhnke methodology in the key step. The chiral moieties of these ligands originate from the monoterpen chiral pool, namely $(-)-\alpha$-pinene $((-)-\mathbf{1 4},(-)-\mathbf{1 5})$ and $(-)$-myrtenal $((-)-9,(-)-10)$. Extension of the above-mentioned asymmetric synthesis procedure to the preparation of enantiopure derivatives of some commonly used polypyridylic ligands has been achieved through a new aldehyde building block ((-)-16). As an example, the synthesis of a chiral derivative of $N, N$-bis(2-pyridylmethyl)ethylamine (bpea) ligand, (-)-19, has been performed to illustrate the viability of the method. The coordinative ability of the ligands has been tested through the synthesis and characterization of complexes $\left[\mathrm{Mn}((-)-\mathbf{1 9}) \mathrm{Br}_{2}\right],(-)-\mathbf{2 0}$, and $[\mathrm{RuCl}((-)-\mathbf{1 0})(\mathrm{bpy})]\left(\mathrm{BF}_{4}\right),(-)-\mathbf{2 1}$. Some preliminary results related to the enantioselective catalytic epoxidation of styrene with the ruthenium complex are also presented.

\section{Introduction}

Transition-metal asymmetric catalysis is one of the most powerful tools for the synthesis of optically active compounds, ${ }^{1}$ and the development of new chiral ligands represents a crucial part in this area. A wide range of chiral mono-, bi-, and multidentate ligands with different coordinating atoms are known today and used extensively for all kinds of catalytic reactions, but only a relatively small number of structural classes stand out due to their broad applicability. Bisoxazolines, ${ }^{2}$ salens, ${ }^{3}$

\footnotetext{
$\dagger$ Universitat de Girona.

\$ Universitat Autònoma de Barcelona.

$\S$ University of Fribourg.

"Institut Català d'Investigació Química.

(1) (a) For reviews, see: Noyori, R.; Ed. Asymmetric Catalysis in Organic Synthesis; Wiley: New York, 1994. (b) Jacobsen, E. N., Pfaltz, A., Yamamoto, H., Eds. Comprehensive Asymmetric Catalysis; Springer: Berlin, 1999. (c) Catalytic Asymmetric Synthesis, 2nd ed.; Ojiwa, I., Ed.; Wiley: New York, 2000. (d) Seyden Penne, J. Chiral Auxiliaries and Ligands in Asymmetric Synthesis; Wiley: New York, 1995.
}

tartrate derivatives, ${ }^{4}$ biarylic phosphines or alcohols, ${ }^{5}$ and cinchona alkaloids 6 are top examples of these "privileged ligands". ${ }^{7}$ Nevertheless, there is still an increasing need for new and improved ligands.

Transition-metal complexes with $\mathrm{sp}^{2}$-nitrogen(s) as coordinating atoms constitute also an important class of coordination compounds able to perform a wide range of asymmetric transformations. ${ }^{8}$ Within this group, substituted mono- and bisoxazolines ${ }^{9}$ have received major attention during the past three decades. Recently, chiral versions of $C_{2}$-symmetric 2,2'bipyridyl, 2,2':6',2'-terpyridines and 1,10-phenanthrolines have been prepared as promising new compounds in this area, ${ }^{10}$ offering novel opportunities such as electronic tuning of the ligating nitrogen via the substitution pattern at the pyridine ring. ${ }^{11}$ However, despite the intrinsic interest of chiral ligands containing $C_{3}$ symmetry, their polypyridylic derivatives have received less attention. ${ }^{12,13}$ Upon coordination to a metal center, 
they can reduce the number of possible diastereomeric intermediates or transition states in a catalytic reaction, ${ }^{14}$ as has been shown for $C_{2}$-symmetric bidentate ligands in the case of tetrahedral and square-planar complexes. ${ }^{15} C_{3}$-Symmetric tridentate ligands could be potentially used to prepare metal complexes for a number of asymmetric catalytic reactions such as allylic substitutions, epoxidations, cyclopropanations, hydrosilylations, etc. ${ }^{10}$ In this context, it will be of special interest to assert the effect of facial versus meridional geometry in octahedral type of complexes, for instance when the more accessible tridentate trpy $C_{2}$-meridional type of ligand (trpy is $2,2^{\prime}: 6^{\prime}, 2^{\prime \prime}$-terpyridine) is replaced by the tripodal ligands described in this work. Metal centers with higher and lower coordination numbers will also be strongly influenced by the

(2) (a) Pfaltz, A. Acc. Chem. Res. 1993, 26, 339-345. (b) Ghoshb, A. K.; Mathivanan, P.; Cappiello, J. Tetrahedron: Asymmetry 1998, 8, 1-45. (c) Jorgensen, K. A.; Johannsen, M.; Yao, S.; Audrain, H.; Thornauge, J. Acc. Chem. Res. 1999, 32, 605-613.

(3) (a) Jacobsen, E. N. Acc. Chem. Res. 2000, 33, 421-431. (b) Myers, J. K.; Jacobsen, E. N. J. Am. Chem. Soc. 1999, 121, 8959-8960. (c) Ruck, T. R.; Jacobsen, E. N. J. Am. Chem. Soc. 2002, 124, 2882-2883.

(4) (a) Katsuki, T.; Martin, V. S. Org. React. 1996, 48, 1-299. (b) Seebach, D.; Beck, A. K.; Heckel, A. Angew. Chem., Int. Ed. 2001, 1, 92139. (c) Johnson, R. A.; Sharpless, K. B. In Catalytic Asymmetric Synthesis; Ojiwa, I., Ed.; Wiley-VCH: New York, 1993; Chapter 4.1.

(5) Noyori, R. Adv. Synth. Catal. 2003, 345, 5-32.

(6) (a) Kolb, H. C.; van Nieuwenze, M. S.; Sharpless, K. B. Chem. Rev. 1994, 94, 2483-2547. (b) Calter, M. A. J. Org. Chem. 1996, 61, 80068007. (c) Dolling, U.-H.; Davis, P.; Grabowski, E. J. J. J. Am. Chem. Soc. 1984, 106, 446-447. (d) Corey, E. J.; Xu, F. Noe, M. C.; J. Am. Chem. Soc. 1997, 119, 12414-12415. (e) Beller, M.; Sharpless, K. B. In Applied Homogeneous Catalysis with Organometallic Compounds; Cornils, B., Herrmann, W. A., Eds.; VCH: Weinheim, 1996; Vol. 2, pp 1009-1024.

(7) Yoon, T. P.; Jacobsen, E. N. Science 2003, 299, 1691-1693.

(8) (a) Togni, A.; Venanzi, L. M. Angew. Chem., Int. Ed. Engl. 1994, 33, 497-526. (b) Fache, F.; Schulz, E.; Lorraine, A.; Tommasino, M. L.; Lemaire, M. Chem. Rev. 2000, 100, 2159-2231.

(9) Selected references: (a) Gomez, M.; Muller, M.; Rocamora, M Coord. Chem. Rev 1999, 193, 769-835. (b) Evans, D. A.; Scheidt, K. A. Johnston, J. N.; Willis, M. C. J. Am. Chem. Soc. 2001, 123, 4480-4491. (c) Christensen, C.; Juhl, K.; Jorgensen, K. A. Chem. Commun. 2001, $2222-$ 2223. (d) Glorius, F.; Pfaltz, A. Org. Lett. 1999, 1, 141-144. (e) BelleminLaponnaz, S.; Gade, L. H. Angew. Chem., Int. Ed. Engl. 2002, 41, $3473-$ 3475. (f) Helmchen, G.; Pfaltz, A. Acc. Chem. Res. 2000, 33, 336-345.

(10) For an overview, see: Chelucci, G.; Thummel, R. P. Chem. Rev. 2002, 102, 3129-3170. Selected references: (a) Fletcher, N. C. J. Chem. Soc., Perkin Trans. 2002, 1831-1842. (b) Ziegler, M.; Monney, V.; Stoeckli-Evans, H.; von Zelewsky, A.; Sasaki, I.; Dupie, G.; Daran, J.-C.; Balavoine, G. G. A. J. Chem. Soc., Dalton Trans. 1999, 667-675. (c) Loetscher, D.; Rupprecht, S.; Collomb, P.; Belser, P.; Viebrock, H.; von Zelewsky, A.; Burger, P. Inorg. Chem. 2001, 40, 5675-5681. (d) Malkov, A. V.; Baxendale, I. R.; Bella, M.; Langer, J. W.; Russell, D. R.; Mansfield, J.: Valko, M.; Kocôvský, P. Organometallics 2001, 20, 673-690. (e) Malkov, A. V.; Pernazza, D.; Bell, M.; Bella, M.; Massa, A.; Teplý, F.; Meghani, P.; Kocôvský, P. J. Org. Chem. 2003, 68, 4727-4742. (f) Harmata, M.; Ghosh, S. K. Org. Lett. 2001, 3, 3321-3323.

(11) (a) Kinnunen, T.-J. J.; Haukka, M.; Nousiainen, M.; Patrikka, A.; Pakkanen, T. A. J. Chem. Soc., Dalton Trans. 2001, 2649-2654. (b) Bush, P. M.; Whitehead, J. P.; Pink, C. C.; Gramm, E. C.; Eglin, J. L.; Watton, S. P.; Pence, L. E. Inorg. Chem. 2001, 40, 1871-1877.

(12) (a) Adolfsson, H.; Wärnmark, K.; Moberg, C. Chem. Commun. 1992 1054-1055. (b) Castaldi, M. P.; Gibson, S. E.; Rudd, M.; White, A. J. P. Angew. Chem., Int. Ed. 2005, 44, 3432-3435. (c) Hamann, C.; von Zelewsky, A.; Neels, A.; Stoeckli-Evans, H. J. Chem. Soc., Dalton Trans. 2004, 402-406. (d) Schaffner-Hamann, C.; von Zelewsky, A.; Barbieri, A.; Barigelletti, F.; Muller, G.; Riehl, J. P.; Neels, A. J. Am. Chem. Soc. 2004, 126, 9339-9348. (e) Castaldi, M. P.; Gibson, S. E.; Rudd, M. White, A. J. P. Chem. Eur. J. 2006, 12, 138-148. (f) Motson, G. R.; Mamula, O.; Jeffery, J. C.; McCleverty, J. A.; Ward, M. D.; von Zelewsky, A. J. Chem. Soc., Dalton Trans. 2001, 1389-1391.

(13) Cotton, F. A. Chemical Applications of Group Theory; Wiley: New York, 1971.

(14) Moberg, C. Angew. Chem., Int. Ed. 1998, 37, 248-268.

(15) Burk, M. J.; Harlow, R. L. Angew. Chem., Int. Ed. Engl. 1990, 29, $1467-1469$ geometry of the tridentate ligand and thus will also be explored in the near future.

With all this in mind, we have been working toward the design of new enantiopure $C_{3}$-symmetric polypyridylic ligands where chirality could be introduced from naturally occurring monoterpenes, as well as in the synthesis of other commonly used polypyridylic compounds through the new aldehyde building block (-)-16 (Scheme 3). We describe here on the preparation and characterization of chiral "pineno"-fused tris(2-pyridyl) tripod ligands (-)-9, (-)-10, (-)-14, and (-)-15 (Schemes 1 and 2) as examples of $C_{3}$-symmetric ligands. On the other hand, the viability of the chiral design to lower symmetry ligands is exemplified by the synthesis of a chiral derivative of $N, N$-bis(2-pyridylmethyl)ethylamine (bpea) ligand (-)-19. Furthermore, the coordinative behavior of some of the ligands to $\mathrm{Mn}$ and $\mathrm{Ru}$, as well as the catalytic activity of the $\mathrm{Ru}$ complex prepared, are described. Finally, it is also interesting to point out that the synthetic route we have designed for the preparation of the chiral tridentate ligands uses dipyridyl ketones $((-)-8$ and (-)-13) as intermediates. These synthetic intermediates are also potentially exciting bidentate chiral ligands ${ }^{16}$ that have been studied to a much lesser extent and that might open up new research territories.

\section{Results and Discussion}

The basic ligands synthesized within this report consist of tris(2-pyridyl)methanols and bis(pyridyl)ethylamine as parent structures. Our strategy was to introduce chirality in commonly used molecules by enantiomerically pure monoterpenes. The synthetic pathway follows the general method for pyridine synthesis introduced by Krönke. ${ }^{17}$ The chirality is introduced via the commercially available natural products $(-)$-myrtenal $(-)-3$ and (-)- $\alpha$-pinene (-)-4, giving annulated compounds in the 4,5- and 5,6-position of a pyridine ring, respectively.

Design of the $\boldsymbol{C}_{3}$-Symmetric Tripodal Ligands. Although $C_{2}$-symmetric ligands have been extensively used for metalmediated enantioselective organic transformations, ${ }^{18}$ analogous $C_{3}$-symmetric systems have been used to a lesser extent. ${ }^{14}$ Metal catalysts containing ligands possessing $C_{3}$ or higher rotational symmetry are expected to permit a higher degree of stereocontrol and reduce the number of possible transition states (in, for instance, octahedral complexes) compared to those for the $C_{2^{-}}$symmetric counterparts and thus may find applications in asymmetric catalysis. These particular characteristics jointly with our experience in the synthesis of chiral pineno-fused pyridines have directed us toward chiral tris-pyridylic ligands. Although the first synthesis of tris(2-pyridyl)methanol ligand dates from more than 50 years ago, ${ }^{19}$ work related to the synthesis of trisubstituted $^{20}$ and chiral ${ }^{12 a}$ derivatives is rare, which is surprising considering their potential applications. This can, at least in part, be attributed to the complexity of the pyridyllithium chemistry $^{21}$ used to prepare this kind of molecules.

(16) Kwong et al. Eur. J. Inorg. Chem. 2000, 1997-2002.

(17) Kröhnke, F. Synthesis-Stuttgart 1976, 1-24.

(18) Selected references: (a) Fletcher, N. C. J. Chem. Soc., Perkin Trans. 2002, 1831-1842. (b) Yoon, P. Y.; Jacobsen, E. N. Science 2003, 299, 1691-1693. (c) Noyori, R. Adv. Synth. Catal. 2003, 345, 5-33. (d) Plaftz, A. Acc. Chem. Res. 1993, 26, 339-345. (e) Dang, T. P.; Kagan, H. B. J. Chem. Soc. D, Chem. Commun. 1971, 481.

(19) Wibaut, J. P.; De Jonge, A. P.; Van Der Voort, H. G. P.; Otto, P. Ph. H. L. Rec. Trav. Chim. Pays-Bas 1951, 70, 1054-1066.

(20) (a) Li, X.; Gibb, C. L. D.; Kuebel, M. E.; Gibb, B. C. Tetrahedron 2001, 1175-1182. (b) Gong, J.; Gibb, B. C. Org. Lett. 2004, 6, 13531356. 


\section{SCHEME 1}

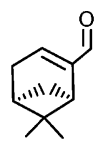

$(-)-3$

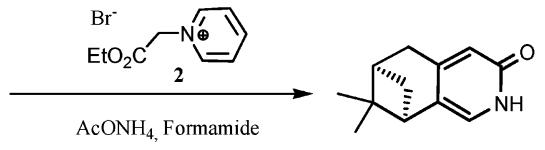

$(-)-6$

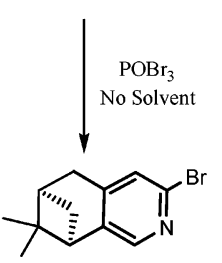

$(-)-7$
$(-)-7$, n-BuLi, THF

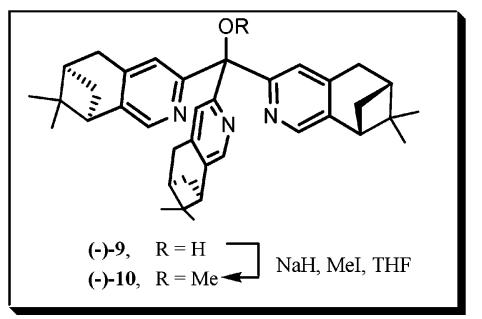

Synthesis of $C_{3}$-Symmetric Tripodal Ligands. (-)-Myrtenal $(-)-\mathbf{3}$ was employed as the starting material in the synthesis of ligands (-)-9 and (-)-10 (Scheme 1). Kröhnke salt $\mathbf{2}$ is obtained from reaction of ethyl 2-bromoacetate with pyridine, according to the literature procedure. ${ }^{10 e}$ Then, pyridone $(-)-6$ has been prepared by condensation of the aldehyde (-)-3 with pyridinium salt $\mathbf{2}$ and dry ammonium acetate under the Kröhnke conditions ${ }^{22}$ applying initially low reaction temperatures $\left(2, \mathrm{AcONH}_{4}\right.$, formamide, $40{ }^{\circ} \mathrm{C}, 3$ days; then $80{ }^{\circ} \mathrm{C}, 3$ days, $150{ }^{\circ} \mathrm{C}, 6 \mathrm{~h}$; $27 \%$ ). This procedure led to a significant yield improvement with respect to the procedure developed by Kocôvský, ${ }^{10 \mathrm{~d}}$ where higher temperatures are employed from the beginning. A measured rise of the reaction temperature during 6 days was needed to avoid the decomposition of (-)-3. Faster reaction profiles were unsuccessful or gave poor yields. Synthesis of bromopyridine (-)-7 was first attempted using inexpensive and environmentally friendly phosphonium salts ${ }^{23}$ under refluxing conditions, but no conversion at all was achieved. Bromination with $\mathrm{POBr}_{3}$ was then tried. However, commonly used conditions

(21) See, for example: (a) Peterson, M. A.; Mitchell, J. R. J. Org. Chem. 1997, 62, 8237-8239. (b) Gu, Y. G.; Bayburt, E. K. Tetrahedron Lett. 1996, 37, 2565-2568. (c) Cai, D.; Hughes, D. L.; Verhoeven, T. R. Tetrahedron Lett. 1996, 37, 2537-2540. (d) Parham, W. E.; Piccirilli, R. M. J. Org. Chem. 1977, 52, 257-260. (e) Mallet, M.; Branger, G.; Marsais, F.; Queguiner, G. J. Organomet. Chem. 1990, 282, 319-332.

(22) For Kröhnke annelation, see: (a) Kröhnke, F.; Heffe, W. Chem. Ber. 1937, 70, 864. For recent overview of its application in the synthesis of terpenoid pyridines and bipyridines, see: (b) Knof, U.; von Zelewsky, A. Angew. Chem., Int. Ed. 1999, 38, 303-322. (c) Düggeli, M.; GoujonGinglier, C.; Richard, S.; Mauron, D.; Bonte, C.; von Zelewsky, A.; StoeckliEvans, H.; Neels, A. Org. Biomol. Chem. 2003, 1, 1894-1899. (d) Chelucci, G.; Thummel, R. P. Chem. Rev. 2002, 102, 3129-3170.

(23) (a) Froyen, P. Phosphorus Sulfur Silicon Relat. Elem. 1995, 102, 253-259. (b) Sugimoto, O.; Mori, M.; Moriya, K.; Tanji, K. I. Helv. Chim. Acta 2001, 1, 1112-1118. (c) Sugimoto, O.; Mori, M.; Tanji, K. I. Tetrahedron Lett. 1999, 40, 7477-7478. with DMF as solvent did not work, and the starting material (-)-6 was quantitatively recovered. Only a stronger procedure without any solvent $\left(140{ }^{\circ} \mathrm{C}, 2.5 \mathrm{~h}\right)$ afforded (-)-7 with a moderate yield (30\%). A two-step approach ${ }^{19 a}$ to trispyridyl ligands (-)-9 and (-)-10 was then chosen since the one pot formation of similar molecules from the constituent pyridine derivatives ${ }^{24 a}$ proved to be a rather inefficient process. Accordingly, lithiation of (-)-7 via metal-halogen exchange with $n$-BuLi (THF, $-78^{\circ} \mathrm{C}, 30 \mathrm{~min}$ ) followed by the slow addition of a solution of diethyl carbonate (THF, $-78{ }^{\circ} \mathrm{C} 2 \mathrm{~h}$ ) gave the expected ketone $(-)-\mathbf{8}^{24}$ in a reasonable yield $(51 \%)$.

Ketone ( $(-) \mathbf{8}$ was then itself treated with the aforementioned lithiate (THF, $\left.-78^{\circ} \mathrm{C}, 1 \mathrm{~h} ;-40{ }^{\circ} \mathrm{C}, 1 \mathrm{~h}\right)$ to generate the trispyridyl methanol ligand (-)-9 (56\%). (-)-9 achiral analogues have shown three different coordination behaviors $\left(\mathrm{N}, \mathrm{N}^{\prime}, \mathrm{N}^{\prime \prime}\right.$ symmetric mode, ${ }^{25} \mathrm{~N}, \mathrm{~N}^{\prime}, \mathrm{O}^{\prime \prime}$ asymmetric mode, ${ }^{26}$ and $\mathrm{N}, \mathrm{N}^{\prime}$, $\mathrm{O}-\mathrm{O}, \mathrm{N}^{\prime \prime}$ bridging mode between two metal centers ${ }^{27}$ ), whereas O-alkylated derivatives have undergone only symmetric $\mathrm{N}, \mathrm{N}^{\prime}$, $\mathrm{N}^{\prime \prime}$-coordination. ${ }^{27}$ Thus, (-)-9 alkylation was performed to achieve a ligand able to generate $C_{3}$-symmetric coordination compounds, avoiding isomeric mixtures. Alkylated ligand (-)10 (Scheme 1) was prepared with a combination of sodium hydride and methyl iodide (THF, $60{ }^{\circ} \mathrm{C}, 16 \mathrm{~h}$ ). Although the ligand contains three nitrogen atoms which could potentially undergo alkylation, attack by the alkoxide was the kinetically favored reaction as indicates the $84 \%$ yield afforded for ether (-)-10.

The synthesis of ligands (-)-14 and (-)-15 (Scheme 2) started with the ene reaction of $(-)$ - $\alpha$-pinene $(-)-4$ with singlet oxygen $^{28}$ that afforded pinocarvone $(+)-5\left(\mathrm{O}_{2}\right.$, tetraphenylporphirine, $(\mathrm{AcO})_{2} \mathrm{O}, \mathrm{DMAP}, \mathrm{CH}_{2} \mathrm{Cl}_{2}, 20{ }^{\circ} \mathrm{C}, 6 \mathrm{~h}$; 99\%), which after condensation with pyridinium salt $\mathbf{2}$ and ammonium acetate, again under the Krönke conditions, ${ }^{16}$ led to pyridone (-)-11 (2, $\mathrm{AcONH}_{4}$, piperidine, EtOH, $80{ }^{\circ} \mathrm{C}, 1 \mathrm{~h}$; then $\mathrm{HCONH}_{2}$, acetic acid, $210{ }^{\circ} \mathrm{C}, 1 \mathrm{~h} ; 45 \%$ ). Bromination of pyridone (-)-11 proved to be more problematic. An analogous process to that shown in Scheme 1 ( 2 equiv of $\mathrm{POBr}_{3}, 140{ }^{\circ} \mathrm{C}$, no solvent) was first attempted, but several byproducts were formed. Subsequent reactions modifying the solvent amount and $\mathrm{POBr}_{3}$ equivalents guided us to the optimal reaction conditions (1.4 equiv of $\mathrm{POBr}_{3}, 2.5 \mathrm{~h}$; then 1.4 equiv of $\mathrm{POBr}_{3}, 2.5 \mathrm{~h}$ ) leading to bromopyridine (-)-12 in a moderate yield $(31 \%)$. Slight changes in reagent proportions lead to a remarkable increase of side products. One- and two-step approaches to trispyridyl ligands (-)-14 and (-)-15 were assayed in this case. In a first attempt we tried the lithiation of $(-)-\mathbf{1 2}$ with $n$-BuLi (THF, $-78{ }^{\circ} \mathrm{C}, 15 \mathrm{~min}$ ) followed by the slow addition of a solution of triphosgene (THF, $-78{ }^{\circ} \mathrm{C}, 2$ min to rt). Unfortunately, only traces of the expected tripodal ligand (-)-14 were obtained, with ketone (-)-13 being the major product $(18 \%)$. Therefore, a two-step procedure similar to the one showed in

(24) (a) Hannon, M. J.; Mayers, P. C.; Taylor, P. C. Tetrahedron Lett. 1998, 39, 8509-8512. (b) Li, X.; Gibb, C. L. D.; Kuebel, M. E.; Gibb, B. C. Tetrahedron 2001, 1175-1182.

(25) (a) Canty, A. J.; Chaichit, N.; Gatehouse, B. M.; George, E. E. Inorg. Chem. 1981, 20, 4293-4300. (b) Szalda, D.; Keene, G. R. Inorg. Chem. 1986, 25, 2795-2799.

(26) White, D. L.; Faller, J. W. Inorg. Chem. 1982, 21, 3119-3122. (b) Keene, F. R.; Szalda, D. J.; Wilson, T. A. Inorg. Chem. 1987, 26, $2211-$ 2216.

(27) Watanabe, M.; Nankawa, T.; Yamada, T.; Kimura, T.; Namiki, K.; Murata, M.; Nishihara, H.; Tachimori, S. Inorg. Chem. 2003, 42, 69776979.

(28) Mihelich, E. D.; Eickhoff, D. J. J. Org. Chem. 1983, 48, 41354137. 


\section{SCHEME 2}
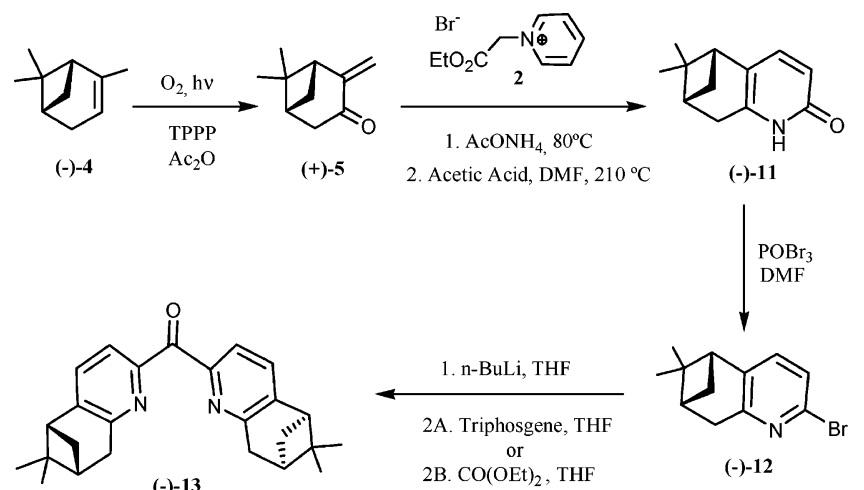

Scheme 1 was attempted. Diethyl carbonate (THF, $-78^{\circ} \mathrm{C}, 2$ h) was added slowly to a solution of (-)-12 lithiate. Ketone (-)-13 was obtained in a reasonable yield (42\%). Subsequent slow addition of $(-)-\mathbf{1 3}$ over the aforementioned lithiate (THF, $-78{ }^{\circ} \mathrm{C}, 2 \mathrm{~h}$ to $\mathrm{rt}$ ) afforded ligand $(-)-\mathbf{1 4}(69 \%)$. Alkylated ligand (-)-15 was prepared again with a combination of sodium hydride and methyl iodide (THF, $60^{\circ} \mathrm{C}, 16 \mathrm{~h}$ ) but with a slightly modified procedure due to the acidic nature of the pinene benzylic protons. Slow addition of $\mathrm{NaH}$ over a solution of $(-)$ 14 and MeI in THF led to ligand (-)-15 in a good yield (80\%) avoiding the formation of side products from pinene alkylation.

All of the 4,5- and 5,6-"pineno-fused" tripodal ligands have been thoroughly characterized via ${ }^{1} \mathrm{H}$ and ${ }^{13} \mathrm{C}$ NMR techniques, which have allowed unambiguous assignment of all the resonances. In a typical ${ }^{1} \mathrm{H}$ NMR, a series of signals comprised in the $\delta=0.5-3.2 \mathrm{ppm}$ region can be found, corresponding to the methyl and methylene groups of the pinene moieties. The resonances corresponding to the pyridyl rings appear in the aromatic region at $\delta$ ranging from 6.3 to $8.1 \mathrm{ppm}$, as singlet or doublet signals depending on the 4,5- or 5,6-substitution on the pyridine ring, respectively. Finally, ESI-MS and elemental analysis measurements were used to precisely confirm the tripodal nature of the ligands, discarding the potential monoand bipodal products which would show relatively similar NMR spectra.

Design of the Bis(pyridyl)ethylamine Tridentate Ligand. Having developed synthetic routes toward chiral $C_{3}$-symmetric "pineno"-fused tpmOR ligands, we envisaged extending these procedures to other commonly used polypyridylic ligands which in some cases involved a reduction in the symmetry while maintaining the chiral character. With this aim in mind, building block (-)-16 (Scheme 3) was synthesized as a potentially powerful tool in ligand design. Aldehyde (-)-16 provides us a general way to obtain the chiral variants of a wide range of polypyridylic ligands. ${ }^{29}$ In this sense, the bis(pyridyl)ethyl amine ligand (bpea) was chosen to illustrate the feasibility of the synthetic method due to our previous experience working with its achiral counterpart. ${ }^{30}$

Synthesis of the Chiral bpea Tridentate Ligand. (-)- $\alpha$ Pinene (-)-4 was also employed as the starting material in the synthesis of ligand (-)-19, initially following the three-step synthetic procedure described in Scheme 2 to obtain the intermediate bromopyridine (-)-12. Then, formation of $(-)$ 12 lithiate ( $n$-BuLi, THF $-78^{\circ} \mathrm{C}, 30 \mathrm{~min}$ ) and subsequent slow addition of DMF in THF $\left(-78{ }^{\circ} \mathrm{C}, 2 \mathrm{~h}\right.$; then $-78{ }^{\circ} \mathrm{C}$ to $\mathrm{rt}$ ) produced aldehyde (-)-16 in 78\% yield (Scheme 3 ). Slow and careful addition of $\mathrm{NaBH}_{4}$ was then employed for the almost quantitative reduction of $(-)-\mathbf{1 6}$ to alcohol $(-)-\mathbf{1 7}(\mathrm{MeOH}, 0$ ${ }^{\circ} \mathrm{C}$ to $\mathrm{rt}, 1 \mathrm{~h}$, then $\left.\mathrm{rt}, 4 \mathrm{~h} ; 99 \%\right)$. Subsequent formation of hydrochloride (-)-18 was achieved with a dropwise addition of $\mathrm{SOCl}_{2}\left(\mathrm{CH}_{2} \mathrm{Cl}_{2}\right.$, overnight; 97\%). Synthesis of ligand (-)19 was finally performed by a double nucleophilic attack of ethylamine over hydrochloride (-)-18 under basic conditions ${ }^{31}$ $\left((-)-18, \mathrm{CH}_{3} \mathrm{CN} / \mathrm{H}_{2} \mathrm{O} 1: 1, \mathrm{EtNH}_{2}, 60{ }^{\circ} \mathrm{C}, 5 \mathrm{~min}\right.$; then $\mathrm{NaOH}$ $10 \%$ dropwise, $60{ }^{\circ} \mathrm{C}, 1 \mathrm{~h}$; then $60{ }^{\circ} \mathrm{C}$ to rt; $59 \%$ ).

Coordination Chemistry and Catalytic Activity. In a preliminary attempt to explore the coordinating ability of the synthesized ligands, chiral bpea (-)-19 was treated with manganese(II) dibromide. $\mathrm{Et}_{2} \mathrm{O}$ addition led to white crystals that where identified as $\left[\mathrm{Mn} \mathrm{Br}_{2}((-)-19)\right]$, complex (-)-20, by X-ray crystallography. An ORTEP plot of the complex structure is shown in Figure S1 of the Supporting Information. The structure shows ligand (-)-19 coordinating to the Mn(II) center through its $\mathrm{N}$ atoms, resulting in a highly distorted trigonal bipyramidal environment. The angle between the two equatorial bromine ligands is $129.5^{\circ}$, and the axial N3a-Mn1a$\mathrm{N} 1 \mathrm{a}$ angle is around $150^{\circ}$, far from the $180^{\circ}$ of the regular geometry. These distortions are mainly due to the structural constrains imposed by the coordination of the chiral bpea ligand which binds the metal center by adopting a quite unusual planar disposition, ${ }^{32}$ with the two pyridyl rings nearly coplanar. The $\mathrm{Mn}-\mathrm{Br}$ bond distances are 2.53 and $2.51 \AA$, and the $\mathrm{Mn}-\mathrm{N}$ bond distances are all slightly larger than $2.2 \AA$.

The coordination behavior of one of the $C_{3}$-symmetric ligands synthesized is exemplified by the synthesis of the complex $[\mathrm{RuCl}((-)-\mathbf{1 0})(\mathrm{bpy})] \mathrm{BF}_{4},(-)-21$ (bpy $=2,2^{\prime}$-bipyridine, see the Supporting Information for experimental details). The structural characterization has been performed in solution through NMR spectroscopy. Ru(II) d $\mathrm{d}^{6}$ ions generally present an octahedral type of geometry, as is the case of (-)-21 with the (-)-10 ligand acting in a facial fashion. The bidentate bpy and the $\mathrm{Cl}$ ligands complete the remaining opposite coordination face of the complex.

(29) Other chiral ligands synthesized using this method: Gómez, L.; Company, A.; Sala, X.; Costas, M.; Llobet, A.; Benet-Buchholz, J. Unpublished results.

(30) (a) Rodríguez, M.; Romero, I.; Llobet, A.; Deronzier, A.; Biner, M.; Parella, T.; Stoeckli-Evans, H. Inorg. Chem. 2001, 40, 4150-4156. (b) Rodríguez, M.; Romero, I.; Sens, C.; Llobet, A.; Deronzier, A. Electrochim. Acta. 2003, 48, 1047-1054. (c) Romero, I.; Rodríguez, M.; Llobet, A.; Collomb-Dunand-Sauthier, M.-N.; Deronzier, A.; Parella, T.; Stoeckli-Evans, H. J. Chem. Soc., Dalton Trans. 2000, 1689-1694. (d) Collomb, M.-N.; Deronzier, A.; Romero, I. J. Electroanal. Chem. 1997, 436, 219-225.

(31) Pal, S.; Chan, M. K.; Armstrong, W. H. J. Am. Chem. Soc. 1992, $114,6398-6406$

(32) Baffert, C.; Romero, I.; Pécaut, A.; Llobet, A.; Deronzier, A.; Collomb, M.-N. Inorg. Chim. Acta 2004, 357, 3430. 


\section{SCHEME 3}
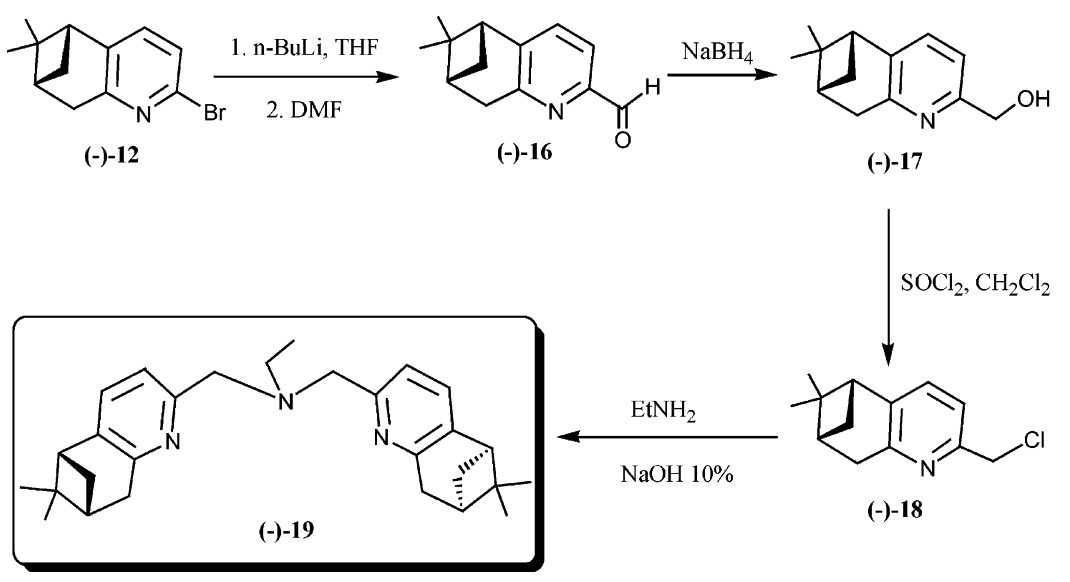

Preliminary results in the catalytic ability of complex (-)21 have been obtained for the epoxidation of styrene in $\mathrm{CH}_{2}-$ $\mathrm{Cl}_{2}$ at room temperature and using $\mathrm{PhI}(\mathrm{OAc})_{2}$ as co-oxidant, with a cat:subs ratio of $1: 100$. After $48 \mathrm{~h}$ reaction time, 0.038 $\mathrm{mM}$ styrene epoxyde ( $48 \%$ conversion) is obtained with a moderate enantioselectivity ( $36 \%$ ee) together with traces of benzaldehyde. While this result clearly manifest the capacity of Ru-complex, containing the pinene ligand, to enantiodifferentiate a prochiral substrate such as styrene, it is obvious that the enantiomeric excess obtained needs to be significantly improved in order to be able to have a meaningful synthetic application. Therefore, further work is in progress to optimize reaction conditions for this system in order to improve enantioselectivities. Furthermore, we are also in the process of developing the coordination chemistry of all of the pinene ligands described in this paper, including bidentate chiral ketones, together with their enantioselective reactivity toward prochiral substrates, with the aim of establishing the best system performances.

\section{Conclusions}

Novel, $C_{3}$-symmetrical trispyridylic ligands have been prepared from (-)- $\alpha$-pinene and (-)-myrtenal via a de novo construction of the pyridine nucleus using Kröhnke annulation as the crucial step. This asymmetric synthetic procedure has been applied, involving a reduction in symmetry, to other commonly used polypyridylic ligands through building block (-)-16 to obtain chiral bpea (-)-19, synthesized to illustrate the feasibility of the method. The coordination behavior of the ligands has been illustrated through the syntheses of a Mn and a Ru metal complexes, and preliminary catalytic results performed with the Ru complex (-)-21 show moderate enantioselectivities in styrene epoxidation with $\mathrm{PhI}(\mathrm{AcO})_{2}$.

\section{Experimental Section}

Syntheses. Starting materials (-)-myrtenal (-)-3 98\% ee, (-)$\alpha$-pinene (-)-4 97\% ee, and ethyl 2-bromoacetate 1 are commercially available. Kröhnke salt $\mathbf{2},{ }^{10 \mathrm{~d}}(+)$-pinocarvone $(+)-\mathbf{5},{ }^{28}$ and pyridone $(-)-\mathbf{1 1}^{10 \mathrm{~d}}$ were obtained following the methods previously described in the literature.

Pyridone (-)-6. Kröhnke salt 2 (15 g, $60.9 \mathrm{mmol})$ and $\mathrm{NH}_{4^{-}}$ OAc were added to a solution of the aldehyde (-)-3 (8.338 g, 55.5 $\mathrm{mmol})$ in formamide $(170 \mathrm{~mL})$. The solution was stirred for 3 days at $40{ }^{\circ} \mathrm{C}, 3$ days at $80{ }^{\circ} \mathrm{C}$, and $6 \mathrm{~h}$ at $150{ }^{\circ} \mathrm{C}$. The mixture was cooled to room temperature, the reaction was quenched with water
(200 mL), and the product was extracted with $\mathrm{CH}_{2} \mathrm{Cl}_{2}(5 \times 150$ $\mathrm{mL})$. The combined organic layers were washed with brine $(150$ $\mathrm{mL})$ and dried $\left(\mathrm{MgSO}_{4}\right)$, and the solvent was removed in vacuo to give a brown oil. That crude was redissolved in formamide (100 $\mathrm{mL})$ and washed with hexane $(6 \times 100 \mathrm{~mL})$. The formamide phase was extracted again with $\mathrm{CH}_{2} \mathrm{Cl}_{2}(5 \times 100 \mathrm{~mL})$, washed with brine $(200 \mathrm{~mL})$, and dried $\left(\mathrm{MgSO}_{4}\right)$, and the solvent was removed in vacuo to give a brown-yellow oil, which was purified via flash chromatography on silica gel with a mixture of $\mathrm{CH}_{2} \mathrm{Cl}_{2}$ /ethyl acetate (1:1) for the elution of secondary products, and with ethyl acetate/ methanol (9:1) to give pure (+)-6 as white crystals (yield $3.146 \mathrm{~g}$, 27\%): mp $141-143{ }^{\circ} \mathrm{C} ;[\alpha]_{\mathrm{D}}-50.3\left(c 1.0, \mathrm{CH}_{2} \mathrm{Cl}_{2}\right)$; IR $v 2930$ m, $1586 \mathrm{w}, 1550 \mathrm{~m}, 1463 \mathrm{~s}, 1360 \mathrm{~s}, 1065 \mathrm{~s} \mathrm{~cm}^{-1}$; ${ }^{1} \mathrm{H}$ NMR (200 $\left.\mathrm{MHz}, \mathrm{CDCl}_{3}\right) \delta 0.66(\mathrm{~s}, 3 \mathrm{H}), 1.16(\mathrm{~d}, J=8.2 \mathrm{~Hz}, 1 \mathrm{H}), 1.33(\mathrm{t}$, $3 \mathrm{H}), 2.15(\mathrm{~m}, 1 \mathrm{H}), 2.60(\mathrm{~m}, 2 \mathrm{H}), 2.88(\mathrm{~d}, J=2.4 \mathrm{~Hz}, 2 \mathrm{H}), 6,39(\mathrm{~s}$, $1 \mathrm{H}), 6.87(\mathrm{~s}, 1 \mathrm{H}) ;{ }^{13} \mathrm{C} \mathrm{NMR}\left(50 \mathrm{MHz}, \mathrm{CDCl}_{3}\right) \delta 21.5\left(\mathrm{CH}_{3}\right), 25.8$ $\left(\mathrm{CH}_{3}\right), 32.2\left(\mathrm{CH}_{2}\right), 32.8\left(\mathrm{CH}_{2}\right), 39.4(\mathrm{C}), 40.1(\mathrm{CH}), 43.8(\mathrm{CH})$, $118.1(\mathrm{CH}), 126.3(\mathrm{C}), 127.5(\mathrm{CH}), 152.3(\mathrm{C}), 165.1(\mathrm{C})$; ESI-MS $(\mathrm{m} / \mathrm{z}) 190[\mathrm{M}+\mathrm{H}]^{+}$. Anal. Calcd for $\mathrm{C}_{12} \mathrm{H}_{15} \mathrm{NO}$ (189.25): C, 76.16; H, 7.99; N, 7.40. Found: C, 76.10; H, 8.02; N, 7.38.

Bromopyridine (-)-7. Pyridone (-)-6 (5.2 g, $27.5 \mathrm{mmol})$ and $\mathrm{POBr}_{3}(13.8 \mathrm{~g}, 48.1 \mathrm{mmol})$ were heated, without solvent, at 140 ${ }^{\circ} \mathrm{C}$ for $2.5 \mathrm{~h}$ and then cooled to $0{ }^{\circ} \mathrm{C}$. The reaction was quenched with ice followed by addition of aqueous $1 \mathrm{M} \mathrm{NaHCO}_{3}(100 \mathrm{~mL})$. The product was extracted with ether $(3 \times 100 \mathrm{~mL})$, the combined organic layers were washed with brine $(100 \mathrm{~mL})$ and dried $\left(\mathrm{MgSO}_{4}\right)$, and the solvent was evaporated in vacuo. The crude product was purified via flash chromatography on silica gel $(40 \mathrm{~g})$ with a hexane/ethyl acetate mixture (10:3) to give crude (-)-7 as a pale yellow oil, which employed in the next step without further purification. An ethyl acetate/methanol mixture (9:1) was then used to recover the not reacted starting material (yield $2.052 \mathrm{~g}, 30 \%$; $57.1 \%$ from starting recovered material): $[\alpha]_{\mathrm{D}}-57.8\left(c 3.7, \mathrm{CH}_{2^{-}}\right.$ $\mathrm{Cl}_{2}$ ); IR $v 2930 \mathrm{~m}, 1586 \mathrm{w}, 1550 \mathrm{~m}, 1463 \mathrm{~s}, 1360 \mathrm{~s}, 1065 \mathrm{~s} \mathrm{~cm}^{-1}$; ${ }^{1} \mathrm{H}$ NMR $\left(200 \mathrm{MHz}, \mathrm{CDCl}_{3}\right) \delta 0.60(\mathrm{~s}, 3 \mathrm{H}), 1.11(\mathrm{~d}, J=9.4 \mathrm{~Hz}$, $1 \mathrm{H}), 1.36(\mathrm{~s}, 3 \mathrm{H}), 2.25(\mathrm{~m}, 1 \mathrm{H}), 2.67(\mathrm{~m}, 2 \mathrm{H}), 2.90(\mathrm{~d}, J=3.0$, 2H), $7.31(\mathrm{~s}, 1 \mathrm{H}), 7.85(\mathrm{~s}, 1 \mathrm{H}) ;{ }^{13} \mathrm{C}$ NMR $\left(50 \mathrm{MHz}, \mathrm{CDCl}_{3}\right) \delta$ $21.4\left(\mathrm{CH}_{3}\right), 25.9\left(\mathrm{CH}_{3}\right), 31.6\left(\mathrm{CH}_{2}\right), 32.6\left(\mathrm{CH}_{2}\right), 39.1(\mathrm{C}), 39.7$ $(\mathrm{CH}), 44.1(\mathrm{CH}), 127.2(\mathrm{CH}), 139.4(\mathrm{C}), 142.0(\mathrm{C}), 146.1(\mathrm{CH})$, $148.0(\mathrm{C})$; ESI-MS $(\mathrm{m} / \mathrm{z}) 253[\mathrm{M}+\mathrm{H}]^{+}$.

Ketone (-)-8. Bromopyridine (-)-7 (3.058 g, $12.1 \mathrm{mmol}$ ) was dissolved in THF $(61 \mathrm{~mL})$ and the resulting solution cooled to -78 ${ }^{\circ} \mathrm{C}$. A solution of $n$-BuLi in hexanes $(12.7 \mathrm{mmol}, 7.96 \mathrm{~mL}$ of a 1.6 $M$ solution) was added dropwise to the cooled solution. After the lithiate solution was stirred for $30 \mathrm{~min}$, a solution of diethyl carbonate $(6.1 \mathrm{mmol}, 0.74 \mathrm{~mL}$ in $15 \mathrm{~mL}$ THF) was slowly added. After further stirring for $2 \mathrm{~h}$ at $-78^{\circ} \mathrm{C}$, the reaction was allowed to warm to ca. $0{ }^{\circ} \mathrm{C}$ and quenched with $10 \% \mathrm{HCl}$ until acidic. The resulting mixture was basified with $10 \%$ aqueous $\mathrm{K}_{2} \mathrm{CO}_{3}$ and then partitioned between $\mathrm{CHCl}_{3}$ and water, and the organic layers were 
combined and dried with anhydrous $\mathrm{MgSO}_{4}$. The solvent was removed under reduced pressure, and the crude product was purified via flash chromatography on silica gel ( $40 \mathrm{~g}$ ) starting with a hexane/ ethyl acetate mixture (10:3) to elute impurities and continuing with a $\mathrm{CH}_{2} \mathrm{Cl}_{2}$ /ethyl acetate mixture (10:1) to give pure (-)-8 as a white solid (yield $1.147 \mathrm{~g}, 51 \%)$ : $\mathrm{mp} 56-58{ }^{\circ} \mathrm{C} ;[\alpha]_{\mathrm{D}}-90\left(c 0.78, \mathrm{CH}_{2-}\right.$ $\mathrm{Cl}_{2}$ ); IR $v 2928 \mathrm{~s}, 1673 \mathrm{vs}, 1591 \mathrm{w}, 1555 \mathrm{w}, 1308 \mathrm{~m}, 1249 \mathrm{~s} \mathrm{~cm}^{-1}$; ${ }^{1} \mathrm{H}$ NMR $\left(200 \mathrm{MHz}, \mathrm{CDCl}_{3}\right) \delta 0.64(\mathrm{~s}, 6 \mathrm{H}), 1.23(\mathrm{~d}, J=9.4 \mathrm{~Hz}$, $2 \mathrm{H}), 1.40(\mathrm{~s}, 6 \mathrm{H}), 2.33(\mathrm{~m}, 2 \mathrm{H}), 2.70(\mathrm{~m}, 2 \mathrm{H}), 2.88(\mathrm{~m}, 2 \mathrm{H}), 3.03$ $(\mathrm{d}, J=2.9,4 \mathrm{H}), 7.45(\mathrm{~s}, 2 \mathrm{H}), 8.04(\mathrm{~s}, 2 \mathrm{H}) ;{ }^{13} \mathrm{C} \mathrm{NMR}(50 \mathrm{MHz}$, $\left.\mathrm{CDCl}_{3}\right) \delta 21.5\left(\mathrm{CH}_{3}\right), 26.0\left(\mathrm{CH}_{3}\right), 31.4\left(\mathrm{CH}_{2}\right), 32.9\left(\mathrm{CH}_{2}\right), 39.1$ (C), $40.0(\mathrm{CH}), 44.8(\mathrm{CH}), 124.8(\mathrm{CH}), 145.2(\mathrm{C}), 145.7(\mathrm{CH})$, 146.0 (C), $153.2(\mathrm{C}), 193.5(\mathrm{C})$; ESI-MS $(\mathrm{m} / \mathrm{z}) 373[\mathrm{M}+\mathrm{H}]^{+}$. Anal. Calcd for $\mathrm{C}_{26} \mathrm{H}_{32} \mathrm{~N}_{2} \mathrm{O} \cdot 0.6 \mathrm{H}_{2} \mathrm{O}$ (383.02): C, 78.34; H, 7.68; N, 7.31. Found: C, 78.69; H, 7.98; N, 7.30.

tpmOH (-)-9. Bromopyridine (-)-7 (1.083 g, $4.3 \mathrm{mmol})$ was dissolved in THF $(60 \mathrm{~mL})$ and the resulting solution cooled to -78 ${ }^{\circ} \mathrm{C}$. A solution of $n$-BuLi in hexanes $(4.5 \mathrm{mmol}, 2.84 \mathrm{~mL}$ of a 1.6 $\mathrm{M}$ solution) was added dropwise to the cooled solution. After the lithiate solution was stirred for $30 \mathrm{~min}$, a solution of ketone (-)-8 (3.8 mmol, $1.438 \mathrm{~g}$ in $9 \mathrm{~mL}$ THF) was slowly added. After further stirring for $2 \mathrm{~h}$ at $-78{ }^{\circ} \mathrm{C}$, the reaction was allowed to warm to ca. $0{ }^{\circ} \mathrm{C}$ and quenched with $10 \% \mathrm{HCl}$ until acidic. The resulting mixture was basified with $10 \%$ aqueous $\mathrm{K}_{2} \mathrm{CO}_{3}$, the crude product was partitioned between $\mathrm{CHCl}_{3}$ and water, and the organic layers were combined and dried with anhydrous $\mathrm{MgSO}_{4}$. The solvent was removed under reduced pressure, and the crude product was purified via flash chromatography on silica gel ( $40 \mathrm{~g})$ with a ethyl acetate/ hexane mixture (10:6) to give pure (-)-9 as a white solid (yield $1.150 \mathrm{~g}, 55 \%): \operatorname{mp~} 91-93{ }^{\circ} \mathrm{C} ;[\alpha]_{\mathrm{D}}-71\left(c 0.69, \mathrm{CH}_{2} \mathrm{Cl}_{2}\right)$; IR $v$ $3300 \mathrm{~m}, 2920 \mathrm{~s}, 1600 \mathrm{w}, 1476 \mathrm{c}, 1425 \mathrm{~m}, 1368 \mathrm{~m} \mathrm{~cm}^{-1}$; ${ }^{1} \mathrm{H}$ NMR $\left(200 \mathrm{MHz}, \mathrm{CDCl}_{3}\right) \delta 0.59(\mathrm{~s}, 9 \mathrm{H}), 1.20(\mathrm{~d}, J=9.4 \mathrm{~Hz}, 3 \mathrm{H}), 1.35$ $(\mathrm{s}, 9 \mathrm{H}), 2.23(\mathrm{~m}, 3 \mathrm{H}), 2.61(\mathrm{~m}, 3 \mathrm{H}), 2.72(\mathrm{~m}, 3 \mathrm{H}), 2.91(\mathrm{~d}, J=1.8$ $\mathrm{Hz}, 6 \mathrm{H}), 7.45(\mathrm{~s}, 3 \mathrm{H}), 8.04(\mathrm{~s}, 3 \mathrm{H}) ;{ }^{13} \mathrm{C} \mathrm{NMR}\left(50 \mathrm{MHz}, \mathrm{CDCl}_{3}\right) \delta$ $21.4\left(\mathrm{CH}_{3}\right), 26.0\left(\mathrm{CH}_{3}\right), 31.6\left(\mathrm{CH}_{2}\right), 32.8\left(\mathrm{CH}_{2}\right), 39.2(\mathrm{C}), 40.1$ $(\mathrm{CH}), 44.3(\mathrm{CH}), 80.9(\mathrm{C}), 121.8(\mathrm{CH}), 14.7(\mathrm{C}), 144.0(\mathrm{C}), 144.7$ $(\mathrm{CH}), 161.4(\mathrm{C})$; ESI-MS $(\mathrm{m} / \mathrm{z}) 547[\mathrm{M}+\mathrm{H}]^{+}$. Anal. Calcd for $\mathrm{C}_{37} \mathrm{H}_{43} \mathrm{~N}_{3} \mathrm{O}$ (545.76): C, 81.43; H, 7.94; N, 7.70. Found: C, 81.24 ; H, 8.20; N, 7.50.

tpmOMe (-)-10. $\mathrm{NaH}(7.2 \mathrm{mmol}, 0.176 \mathrm{~g}$ of a $60 \%$ oil dispersion) was washed twice with pentane and added to $60 \mathrm{~mL}$ of THF. To this stirring mixture were added alcohol (-)-9 (0.8 g, 1.5 $\mathrm{mmol})$ and $\mathrm{MeI}(0.45 \mathrm{~mL}, 7.2 \mathrm{mmol})$. The reaction was stirred at $60{ }^{\circ} \mathrm{C}$ for $16 \mathrm{~h}$. After being cooled to room temperature, the mixture was quenched with $10 \% \mathrm{HCl}$ until acidic and then basified with $10 \%$ aqueous $\mathrm{K}_{2} \mathrm{CO}_{3}$. The crude product was then partitioned between $\mathrm{CHCl}_{3}$ and water, and the aqueous layer was washed twice with $\mathrm{CHCl}_{3}$. The organic layers were combined and dried with anhydrous $\mathrm{MgSO}_{4}$, and the solvent was removed under reduced pressure. The crude product was purified via flash chromatography on silica gel $(30 \mathrm{~g})$ with a acetone/hexane/triethylamine mixture (4:10:0.2) to give pure (-)-10 as a white solid (yield $0.7 \mathrm{~g}, 84 \%$ ): mp $109-111^{\circ} \mathrm{C} ;[\alpha]_{\mathrm{D}}-56.3\left(c 0.36, \mathrm{CH}_{2} \mathrm{Cl}_{2}\right)$; IR $v 2912 \mathrm{~s}, 1600$ w, $1479 \mathrm{~m}, 1425 \mathrm{~m}, 1382 \mathrm{~m}, 1086 \mathrm{~s} \mathrm{~cm}^{-1}$; ${ }^{1} \mathrm{H}$ NMR $(200 \mathrm{MHz}$, $\left.\mathrm{CDCl}_{3}\right) \delta 0.59(\mathrm{~s}, 9 \mathrm{H}), 1.23(\mathrm{~d}, J=9.4 \mathrm{~Hz}, 3 \mathrm{H}), 1.33(\mathrm{~s}, 9 \mathrm{H}), 2.22$ $(\mathrm{m}, 3 \mathrm{H}), 2.61(\mathrm{~m}, 3 \mathrm{H}), 2.74(\mathrm{~m}, 3 \mathrm{H}), 2.91(\mathrm{~d}, J=2.7 \mathrm{~Hz}, 6 \mathrm{H})$, $3.24(\mathrm{~s}, 3 \mathrm{H}), 7.41(\mathrm{~s}, 3 \mathrm{H}), 8.08(\mathrm{~s}, 3 \mathrm{H}) ;{ }^{13} \mathrm{C} \mathrm{NMR}\left(50 \mathrm{MHz}, \mathrm{CDCl}_{3}\right)$ d $21.4\left(\mathrm{CH}_{3}\right), 26.0\left(\mathrm{CH}_{3}\right), 31.7\left(\mathrm{CH}_{2}\right), 32.9\left(\mathrm{CH}_{2}\right), 39.2(\mathrm{C}), 40.2$ $(\mathrm{CH}), 44.3(\mathrm{CH}), 52.8\left(\mathrm{CH}_{3}\right), 88.1(\mathrm{C}), 123.0(\mathrm{CH}), 140.4(\mathrm{C}), 144.3$ (C), $144.7(\mathrm{CH}), 159.7(\mathrm{C})$; ESI-MS $(\mathrm{m} / z) 560[\mathrm{M}+\mathrm{H}]^{+}$. Anal. Calcd for $\mathrm{C}_{38} \mathrm{H}_{45} \mathrm{~N}_{3} \mathrm{O}(559.78)$ : C, 81.53; H, 8.10; N, 7.51. Found: $\mathrm{C}, 81.25 ; \mathrm{H}, 8.35 ; \mathrm{N}, 7.29$.

Bromopyridine (-)-12. Pyridone (-)-11 (6.2 g, $37.79 \mathrm{mmol})$ was dissolved in DMF (13.8 mL), and $\mathrm{POBr}_{3}(13.8 \mathrm{~g}, 44.2 \mathrm{mmol})$ was added. The resulting solution was heated at $140{ }^{\circ} \mathrm{C}$ for $2.5 \mathrm{~h}$ and then cooled to $0{ }^{\circ} \mathrm{C}$. The reaction was quenched with ice followed by aqueous $1 \mathrm{M} \mathrm{NaHCO}_{3}(100 \mathrm{~mL})$. The product was extracted with ether $(3 \times 100 \mathrm{~mL})$, the combined organic layers were washed with brine $(100 \mathrm{~mL})$ and dried $\left(\mathrm{MgSO}_{4}\right)$, and the solvent was evaporated in vacuo. The crude product was purified via flash chromatography on silica gel (40 g) with a hexane/ethyl acetate mixture (10:3) to give (-)-12 as a pale yellow which was employed in the next step without further purification. An ethyl acetate/methanol mixture $(9: 1)$ was used to recover the not reacted starting material (yield $2.540 \mathrm{~g}, 31 \%$; $46 \%$ from starting recovered material): $[\alpha]_{\mathrm{D}}-55.4\left(\right.$ c 3.9, $\left.\mathrm{CH}_{2} \mathrm{Cl}_{2}\right)$; IR $v 2924 \mathrm{~m}, 1580 \mathrm{w}, 1555$ m, $1428 \mathrm{~s}, 1096 \mathrm{~s} \mathrm{~cm}^{-1}$; ${ }^{1} \mathrm{H}$ NMR $\left(200 \mathrm{MHz}, \mathrm{CDCl}_{3}\right) \delta 0.62(\mathrm{~s}$, $3 \mathrm{H}), 1.22(\mathrm{~d}, J=9.4 \mathrm{~Hz}, 1 \mathrm{H}), 1.36(\mathrm{~s}, 3 \mathrm{H}), 2.32(\mathrm{~m}, 1 \mathrm{H}), 2.69(\mathrm{~m}$, 2H), 3.07 (d, $J=3.5 \mathrm{~Hz}, 2 \mathrm{H}), 7.03$ (d, $J=7.9 \mathrm{~Hz}, 1 \mathrm{H}), 7.14$ (d, $J=8.1 \mathrm{~Hz}, 1 \mathrm{H}) ;{ }^{13} \mathrm{C}$ NMR $\left(50 \mathrm{MHz}, \mathrm{CDCl}_{3}\right) \delta 21.2\left(\mathrm{CH}_{3}\right), 25.9$ $\left(\mathrm{CH}_{3}\right), 31.7\left(\mathrm{CH}_{2}\right), 36.4\left(\mathrm{CH}_{2}\right), 39.2(\mathrm{C}), 39.9(\mathrm{CH}), 45.8(\mathrm{CH})$, $124.3(\mathrm{CH}), 135.5(\mathrm{CH}), 138.0(\mathrm{C}), 142.1(\mathrm{C}), 158.2(\mathrm{C})$; ESI-MS $(\mathrm{m} / \mathrm{z}) 253[\mathrm{M}+\mathrm{H}]^{+}$

Ketone (-)-13. Method A. Bromopyridine (-)-12 (1.9 g, 7.52 mmol) was dissolved in THF $(10 \mathrm{~mL})$ and the resulting solution cooled to $-78{ }^{\circ} \mathrm{C}$. A solution of $n$-BuLi in hexanes $(8.21 \mathrm{mmol}$, $5.182 \mathrm{~mL}$ of a $1.6 \mathrm{M}$ solution) was added dropwise to the cooled solution. After the solution was stirred for $30 \mathrm{~min}$, a solution of triphosgene ( $3.11 \mathrm{mmol}, 0.922 \mathrm{~g}$ in $1.85 \mathrm{~mL}$ THF) was added slowly over $1 \mathrm{~min}$. Stirring was continued at $-78{ }^{\circ} \mathrm{C}$ for $2 \mathrm{~min}$ before removal of the cooling bath. After the mixture had warmed to room temperature, $2 \mathrm{~N} \mathrm{H}_{2} \mathrm{SO}_{4}(5 \mathrm{~mL})$ was added and shaken well. The organic layer was separated and further extracted with 2 $\mathrm{N}_{2} \mathrm{SO}_{4}(4 \times 5 \mathrm{~mL})$. The combined acidic extracts were neutralized ( $40 \%$ aqueous $\mathrm{KOH}$ ) and extracted with diethyl ether $(4 \times 50 \mathrm{~mL})$. The combined ether extracts were dried $\left(\mathrm{MgSO}_{4}\right)$, filtered, and evaporated. The crude oil was purified by flash chromatography on silica gel (40 g) with a hexane/ethyl acetate mixture (1:2) to give pure (-)-13 as a white solid (yield $0.250 \mathrm{~g}$, 18\%). Method B. Bromopyridine (-)-12 (1.0 g, $3.7 \mathrm{mmol})$ was dissolved in THF $(20 \mathrm{~mL})$ and the resulting solution cooled to -78 ${ }^{\circ} \mathrm{C}$. A solution of $n$-BuLi in hexanes $(4.2 \mathrm{mmol}, 2.63 \mathrm{~mL}$ of a 1.6 $\mathrm{M}$ solution) was added dropwise to the cooled solution. After the lithiate solution was stirred for $10 \mathrm{~min}$, a solution of diethyl carbonate $(1.24 \mathrm{mmol}, 0.150 \mathrm{~mL}$ in $7 \mathrm{~mL}$ THF) was slowly added. After being stirred for $2 \mathrm{~h}$ at $-78^{\circ} \mathrm{C}$, the reaction was allowed to warm to ca. $0{ }^{\circ} \mathrm{C}$ and was quenched with $10 \% \mathrm{HCl}$ until acidic. The resulting mixture was basified with $10 \%$ aqueous $\mathrm{K}_{2} \mathrm{CO}_{3}$, the crude product was partitioned between $\mathrm{CHCl}_{3}$ and water, the organic layers were combined and dried with anhydrous $\mathrm{MgSO}_{4}$, and the solvent was removed under reduced pressure. The crude product was purified via flash chromatography on silica gel (40 g) starting with a hexane/ethyl acetate mixture (10:3) to elute impurities and continuing with a $\mathrm{CH}_{2} \mathrm{Cl}_{2}$ /ethyl acetate mixture (10:1) to give pure (-)-13 as a white solid (yield $0.310 \mathrm{~g}, 42 \%$ ): $\mathrm{mp} 61-63{ }^{\circ} \mathrm{C} \mathrm{dec}$; $[\alpha]_{\mathrm{D}}-157.7\left(c 0.37, \mathrm{CH}_{2} \mathrm{Cl}_{2}\right)$; IR $v 2922 \mathrm{~s}, 1668 \mathrm{vs}, 1567 \mathrm{~m}, 1422$ $\mathrm{m}, 1244 \mathrm{~m}, 1000 \mathrm{~m} \mathrm{~cm}^{-1}$; ${ }^{1} \mathrm{H}$ NMR $\left(200 \mathrm{MHz}, \mathrm{CDCl}_{3}\right) \delta 0.67(\mathrm{~s}$, $6 \mathrm{H}), 1.28(\mathrm{~d}, J=9.4 \mathrm{~Hz}, 2 \mathrm{H}), 1.41(\mathrm{~s}, 6 \mathrm{H}), 2.39(\mathrm{~m}, 2 \mathrm{H}), 2.71(\mathrm{~m}$, 2H), $2.84(\mathrm{~m}, 2 \mathrm{H}), 3.18(\mathrm{~d}, J=2.9 \mathrm{~Hz}, 4 \mathrm{H}), 7.32(\mathrm{~d}, J=7.7 \mathrm{~Hz}$, $2 \mathrm{H}), 7.85(\mathrm{~d}, J=7.6 \mathrm{~Hz}, 2 \mathrm{H}) ;{ }^{13} \mathrm{C} \mathrm{NMR}\left(50 \mathrm{MHz}, \mathrm{CDCl}_{3}\right) \delta 21.4$ $\left(\mathrm{CH}_{3}\right), 26.0\left(\mathrm{CH}_{3}\right), 31.6\left(\mathrm{CH}_{2}\right), 36.6\left(\mathrm{CH}_{2}\right), 39.5(\mathrm{C}), 40.1(\mathrm{CH})$, $46.9(\mathrm{CH}), 123.8(\mathrm{CH}), 133.0(\mathrm{CH}), 145.5(\mathrm{C}), 151.7(\mathrm{C}), 156.9$ (C), 192.1 (C); ESI-MS $(\mathrm{m} / \mathrm{z}) 373[\mathrm{M}+\mathrm{H}]^{+}$. Anal. Calcd for $\mathrm{C}_{26} \mathrm{H}_{32} \mathrm{~N}_{2} \mathrm{O} \cdot 0.4 \mathrm{H}_{2} \mathrm{O}$ (379.42): C, 79.08; H, 7.65; N, 7.38. Found: C, 79.29; H, 8.01; N, 7.51.

tpmOH (-)-14. Bromopyridine (-)-12 (0.174 g, $0.69 \mathrm{mmol})$ was dissolved in THF ( $9 \mathrm{~mL})$ and the resulting solution cooled to $-78{ }^{\circ} \mathrm{C}$. A solution of $n$-BuLi in hexanes $(0.71 \mathrm{mmol}, 0.448 \mathrm{~mL}$ of a $1.6 \mathrm{M}$ solution) was added dropwise to the cooled solution. After the lithiate solution was stirred for $10 \mathrm{~min}$, a solution of ketone $(-)-13(0.68 \mathrm{mmol}, 0.230 \mathrm{~g}$ in $1.4 \mathrm{~mL}$ THF) was slowly added. After being stirred for $2 \mathrm{~h}$ at $-78^{\circ} \mathrm{C}$, the reaction was allowed to warm to ca. $0{ }^{\circ} \mathrm{C}$ and quenched with $10 \% \mathrm{HCl}$ until acidic. The resulting mixture was basified with $10 \%$ aqueous $\mathrm{K}_{2} \mathrm{CO}_{3}$, the crude product was partitioned between $\mathrm{CHCl}_{3}$ water, the organic layers were combined and dried with anhydrous $\mathrm{MgSO}_{4}$, and the solvent was removed under reduced pressure. The crude product was purified via flash chromatography on silica gel ( $40 \mathrm{~g})$ with a hexane/ 
acetone mixture (10:1) to give pure $(-)-\mathbf{1 4}$ as a white solid (yield $0.230 \mathrm{~g}, 69 \%): \operatorname{mp~} 92-94{ }^{\circ} \mathrm{C} ;[\alpha]_{\mathrm{D}}-80.5\left(c 0.41, \mathrm{CH}_{2} \mathrm{Cl}_{2}\right)$; IR $v$ 3307 m, 2918 s, 1575 w, 1442 m, 1424 m, 1253 w, $1094 \mathrm{~m} \mathrm{~cm}^{-1}$; ${ }^{1} \mathrm{H}$ NMR $\left(200 \mathrm{MHz}, \mathrm{CDCl}_{3}\right) \delta 0.67(\mathrm{~s}, 9 \mathrm{H}), 1.23(\mathrm{~d}, J=9.4 \mathrm{~Hz}$, $3 \mathrm{H}), 1.34$ (s, 9H), $2.25(\mathrm{~m}, 3 \mathrm{H}), 2.57(\mathrm{~m}, 6 \mathrm{H}), 2.91(\mathrm{~d}, J=2.4 \mathrm{~Hz}$, $6 \mathrm{H}), 6.31(\mathrm{~d}, J=7.9 \mathrm{~Hz}, 3 \mathrm{H}), 7.17(\mathrm{~d}, J=8.5 \mathrm{~Hz}, 3 \mathrm{H}) ;{ }^{13} \mathrm{C} \mathrm{NMR}$ $\left.\left(50 \mathrm{MHz}, \mathrm{CDCl}_{3}\right) \delta 21.2\left(\mathrm{CH}_{3}\right), 26.2\left(\mathrm{CH}_{3}\right), 31.9 \mathrm{CH}_{2}\right), 36.4\left(\mathrm{CH}_{2}\right)$, $39.4(\mathrm{C}), 40.3(\mathrm{CH}), 46.3(\mathrm{CH}), 81.0(\mathrm{C}), 119.3(\mathrm{CH}), 132.8(\mathrm{CH})$, 139.7 (C), 154.9 (C), 160.6 (C); ESI-MS $(\mathrm{m} / z) 547[\mathrm{M}+\mathrm{H}]^{+}$. Anal. Calcd for $\mathrm{C}_{37} \mathrm{H}_{43} \mathrm{~N}_{3} \mathrm{O}$ (545.76): C, 81.43; H, 7.94; N, 7.70. Found: C, 81.24; H, 8.20; N, 7.50.

tpmOMe (-)-15. Alcohol (-)-14 (0.136 g, $0.255 \mathrm{mmol})$ and MeI $(0.45 \mathrm{~mL}, 7.2 \mathrm{mmol})$ were mixed in $10 \mathrm{~mL}$ of dry THF. Then, $\mathrm{NaH}(0.4 \mathrm{mmol}, 0.016 \mathrm{~g}$ of a $60 \%$ oil dispersion) washed twice with pentane was added to the former solution. The reaction was stirred at $60{ }^{\circ} \mathrm{C}$ for $4 \mathrm{~h}$. After being cooled to room temperature, the mixture was quenched with $10 \% \mathrm{HCl}$ until acidic and then basified with $10 \%$ aqueous $\mathrm{K}_{2} \mathrm{CO}_{3}$. The crude product was then partitioned between $\mathrm{CHCl}_{3}$ and water, and the aqueous layer was washed twice with $\mathrm{CHCl}_{3}$. The organic layers were combined and dried with anhydrous $\mathrm{MgSO}_{4}$, and the solvent was removed under reduced pressure. The crude product was purified via flash chromatography on silica gel (30 g) with a acetone/hexane/ triethylamine mixture $(4: 10: 0.2)$ to give pure $(-)-\mathbf{1 5}$ as a white solid (yield $0.140 \mathrm{~g}, 84 \%$ ): $\mathrm{mp} 107-109{ }^{\circ} \mathrm{C}$; $[\alpha]_{\mathrm{D}}-118.2(c 1.1$, $\mathrm{CH}_{2} \mathrm{Cl}_{2}$ ); IR $v 2920 \mathrm{~s}, 1574 \mathrm{w}, 1466 \mathrm{~m}, 1423 \mathrm{~m}, 1094 \mathrm{~m} \mathrm{~cm}^{-1} ;{ }^{1} \mathrm{H}$ NMR $\left(200 \mathrm{MHz}, \mathrm{CDCl}_{3}\right) \delta 0.59(\mathrm{~s}, 9 \mathrm{H}), 1.23(\mathrm{~d}, J=9.4 \mathrm{~Hz}, 3 \mathrm{H})$, $1.33(\mathrm{~s}, 9 \mathrm{H}), 2.22(\mathrm{~m}, 3 \mathrm{H}), 2.61(\mathrm{~m}, 3 \mathrm{H}), 2.74(\mathrm{~m}, 3 \mathrm{H}), 2.91(\mathrm{~d}, J$ $=2.6 \mathrm{~Hz}, 6 \mathrm{H}), 3.24(\mathrm{~s}, 3 \mathrm{H}), 7.41(\mathrm{~d}, J=7.9 \mathrm{~Hz}, 3 \mathrm{H}), 8.08(\mathrm{~d}, J$ $=7.6 \mathrm{~Hz}, 3 \mathrm{H}) .{ }^{13} \mathrm{C}$ NMR $\left(50 \mathrm{MHz}, \mathrm{CDCl}_{3}\right) \delta 21.2\left(\mathrm{CH}_{3}\right), 26.0$ $\left(\mathrm{CH}_{3}\right), 29.7\left(\mathrm{CH}_{2}\right), 31.8\left(\mathrm{CH}_{2}\right), 35.6(\mathrm{C}), 39.4(\mathrm{CH}), 46.3(\mathrm{CH})$, $120.6(\mathrm{CH}), 132.7(\mathrm{C}), 139.6(\mathrm{CH}), 155.3(\mathrm{C}), 159.1(\mathrm{C})$; ESI-MS $(\mathrm{m} / \mathrm{z}) 561[\mathrm{M}+\mathrm{H}]^{+}$. Anal. Calcd for $\mathrm{C}_{38} \mathrm{H}_{45} \mathrm{~N}_{3} \mathrm{O}$ (559.78): C, 81.53; H 8.10; N7.51. Found: C, 81.69; H, 8.30; N, 7.31.

Aldehyde (-)-16. Bromopyridine (-)-12 (1.369 g, $5.42 \mathrm{mmol})$ was dissolved in THF $(61 \mathrm{~mL})$ and the resulting solution cooled to $-78{ }^{\circ} \mathrm{C}$. A solution of $n$-BuLi in hexanes $(5.66 \mathrm{mmol}, 3.55 \mathrm{~mL}$ of a 1.6 M solution) was added dropwise to the cooled solution. After the lithiate solution was stirred for $30 \mathrm{~min}$, DMF $(0.46 \mathrm{~mL}, 5.93$ mmol in $0.903 \mathrm{~mL}$ of THF) was added. After being stirred for $2 \mathrm{~h}$ at $-78{ }^{\circ} \mathrm{C}$, the reaction was allowed to warm to ca. $0{ }^{\circ} \mathrm{C}$ and quenched with $6 \mathrm{~N} \mathrm{HCl}(2 \mathrm{~mL})$. The crude product was partitioned between $\mathrm{CHCl}_{3}$ and water, the organic layers were combined and dried with anhydrous $\mathrm{MgSO}_{4}$, and the solvent was removed under reduced pressure. The crude product was purified via flash chromatography on silica gel (40 g) starting with a hexane/ethyl acetate mixture (10:2) to give pure (-)-16 as an orange-yellow oil (yield $0.85 \mathrm{~g}, 78 \%$ ): $[\alpha]_{\mathrm{D}}-84.4\left(c 1.35, \mathrm{CH}_{2} \mathrm{Cl}_{2}\right)$; IR $v 2925 \mathrm{~s}$, 1705 vs, $1570 \mathrm{~m}, 1421 \mathrm{~m}, 1233 \mathrm{~m} \mathrm{~cm}^{-1}$; ${ }^{1} \mathrm{H}$ NMR $(200 \mathrm{MHz}$, $\left.\mathrm{CDCl}_{3}\right) \delta 0.66(\mathrm{~s}, 3 \mathrm{H}), 1.28(\mathrm{~d}, J=9.7 \mathrm{~Hz}, 1 \mathrm{H}), 1.44(\mathrm{~s}, 3 \mathrm{H}), 2.44$ $(\mathrm{m}, 1 \mathrm{H}), 2.80(\mathrm{~m}, 2 \mathrm{H}), 3.21(\mathrm{~d}, J=3.3 \mathrm{~Hz}, 2 \mathrm{H}), 7.38(\mathrm{~d}, J=7.6$ $\mathrm{Hz}, 1 \mathrm{H}), 7.70(\mathrm{~d}, J=7.9 \mathrm{~Hz}, 1 \mathrm{H}), 10.04(\mathrm{~s}, 1 \mathrm{H}) ;{ }^{13} \mathrm{C}$ NMR $(50$ $\left.\mathrm{MHz}, \mathrm{CDCl}_{3}\right) \delta 21.2\left(\mathrm{CH}_{3}\right), 25.9\left(\mathrm{CH}_{3}\right), 31.5\left(\mathrm{CH}_{2}\right), 36.3\left(\mathrm{CH}_{2}\right)$, $39.4(\mathrm{C}), 39.9(\mathrm{CH}), 46.9(\mathrm{CH}), 119.6(\mathrm{CH}), 133.5(\mathrm{CH}), 146.6$ (C), $150.7(\mathrm{C}), 157.8(\mathrm{C}), 193.1(\mathrm{CH})$; ESI-MS $(\mathrm{m} / \mathrm{z}) 202[\mathrm{M}+$ $\mathrm{H}]^{+}$. Anal. Calcd for $\mathrm{C}_{13} \mathrm{H}_{15} \mathrm{NO}$ (201.12): C, 77.58; H, 7.51; N, 7.95. Found: $\mathrm{C}, 77.36 ; \mathrm{H}, 7.82 ; \mathrm{N}, 7.55$.

Alcohol (-)-17. Aldehyde (-)-16 (0.85 g, $4.1 \mathrm{mmol})$ was dissolved in $\mathrm{CH}_{3} \mathrm{OH}(10 \mathrm{~mL})$. The solution was cooled to $0{ }^{\circ} \mathrm{C}$ with an ice bath, and $\mathrm{NaBH}_{4}(0.302 \mathrm{~g}, 8.0 \mathrm{mmol})$ was added portionwise (caution, reaction is exothermic and $\mathrm{H}_{2}$ vapors are vigorously expelled). The reaction was then warmed to room temperature and allowed to stir for $4 \mathrm{~h}$. Then, the solvent was removed under reduced pressure and the residue partitioned between $\mathrm{CH}_{2} \mathrm{Cl}_{2}(10 \mathrm{~mL})$ and $\mathrm{H}_{2} \mathrm{O}(8 \mathrm{~mL})$. The organic phase was separated and the aqueous phase extracted with $\mathrm{CH}_{2} \mathrm{Cl}_{2}(2 \times 15 \mathrm{~mL})$. Combined organic phases were dried over $\mathrm{MgSO}_{4}$, filtered, and evaporated to obtain the title product as a colorless oil (yield: 0.85 g, 99\%): $[\alpha]_{\mathrm{D}}-62\left(c 1.0, \mathrm{CH}_{2} \mathrm{Cl}_{2}\right)$; IR $v 3319 \mathrm{~m}, 2923 \mathrm{~s}, 1535 \mathrm{~m}$,
$1476 \mathrm{~s}, 1363 \mathrm{~s}, 1064 \mathrm{~s} \mathrm{~cm}^{-1} ;{ }^{1} \mathrm{H}$ NMR $\left(200 \mathrm{MHz}, \mathrm{CDCl}_{3}\right) \delta 0.60$ $(\mathrm{s}, 3 \mathrm{H}), 1.22(\mathrm{~d}, J=9.1 \mathrm{~Hz}, 1 \mathrm{H}), 1.37(\mathrm{~s}, 3 \mathrm{H}), 2.34(\mathrm{~m}, 1 \mathrm{H}), 2.66$ $(\mathrm{m}, 2 \mathrm{H}), 3.05(\mathrm{~d}, J=2.7 \mathrm{~Hz}, 2 \mathrm{H}), 6.91(\mathrm{~d}, J=7.7 \mathrm{~Hz}, 1 \mathrm{H}), 7.15$ $(\mathrm{d}, J=7.4 \mathrm{~Hz}, 1 \mathrm{H}) ;{ }^{13} \mathrm{C} \mathrm{NMR}\left(50 \mathrm{MHz}, \mathrm{CDCl}_{3}\right) \delta 21.2\left(\mathrm{CH}_{3}\right)$, $26.0\left(\mathrm{CH}_{3}\right), 32.0\left(\mathrm{CH}_{2}\right), 36.3\left(\mathrm{CH}_{2}\right), 39.4(\mathrm{C}), 40.2(\mathrm{CH}), 46.2(\mathrm{CH})$, $64.3\left(\mathrm{CH}_{2}\right), 117.2(\mathrm{CH}), 133.6(\mathrm{CH}), 140.5(\mathrm{C}), 155.1(\mathrm{C}), 156.0$ (C); ESI-MS $(\mathrm{m} / \mathrm{z}) 204[\mathrm{M}+\mathrm{H}]^{+}$. Anal. Calcd for $\mathrm{C}_{13} \mathrm{H}_{17} \mathrm{NO}$ (203.13): C, 76.81; H, 8.43; N, 6.89. Found: C, 76.57; H, 8.49; $\mathrm{N}, 6.62$.

Chloride (-)-18. Alcohol (-)-17 (0.85 g, $4.18 \mathrm{mmol})$ was dissolved in $\mathrm{CH}_{2} \mathrm{Cl}_{2}(10 \mathrm{~mL})$. A solution of $\mathrm{SOCl}_{2}(0.938 \mathrm{~mL}, 12.5$ mmol) in $\mathrm{CH}_{2} \mathrm{Cl}_{2}(8 \mathrm{~mL})$ was added dropwise to the first solution. The reaction was allowed to stir overnight. Then, the solvent was removed under reduced pressure and the residue partitioned between $\mathrm{CH}_{2} \mathrm{Cl}_{2}(100 \mathrm{~mL})$ and $\mathrm{NaOH} 0.4 \mathrm{M}(100 \mathrm{~mL})$. The organic phase was separated and the aqueous phase extracted with $\mathrm{CH}_{2} \mathrm{Cl}_{2}(2 \times$ $100 \mathrm{~mL}$ ). Combined organic phases were dried over $\mathrm{MgSO}_{4}$, filtered, and evaporated to obtain the title product as a yellow oil (yield $0.91 \mathrm{~g}, 98 \%)$ : $[\alpha]_{\mathrm{D}}-74.3\left(c 0.88, \mathrm{CH}_{2} \mathrm{Cl}_{2}\right)$; IR $v 2922 \mathrm{~s}$, $1583 \mathrm{~m}, 1448 \mathrm{~m}, 1442 \mathrm{~m}, 1253 \mathrm{~s} \mathrm{~cm}{ }^{-1}$; ${ }^{1} \mathrm{H}$ NMR $(200 \mathrm{MHz}$, $\left.\mathrm{CDCl}_{3}\right) \delta 0.53(\mathrm{~s}, 3 \mathrm{H}), 1.15(\mathrm{~d}, J=9.4 \mathrm{~Hz}, 1 \mathrm{H}), 1.29(\mathrm{~s}, 3 \mathrm{H}), 2.27$ $(\mathrm{m}, 1 \mathrm{H}), 2.60(\mathrm{~m}, 2 \mathrm{H}), 3.00(\mathrm{~d}, J=2.3 \mathrm{~Hz}, 2 \mathrm{H}), 4.02(\mathrm{~s}, 1 \mathrm{H}), 7.03$ $(\mathrm{d}, J=7.6 \mathrm{~Hz}, 1 \mathrm{H}), 7.1(\mathrm{~d}, J=7.7 \mathrm{~Hz}, 1 \mathrm{H}) ;{ }^{13} \mathrm{C} \mathrm{NMR}(50 \mathrm{MHz}$, $\left.\mathrm{CDCl}_{3}\right) \delta 21.0\left(\mathrm{CH}_{3}\right), 25.8\left(\mathrm{CH}_{3}\right), 31.6\left(\mathrm{CH}_{2}\right), 36.2\left(\mathrm{CH}_{2}\right), 39.2$ (C), $39.9(\mathrm{CH}), 46.1(\mathrm{CH}), 46.8\left(\mathrm{CH}_{2}\right), 119.3(\mathrm{CH}), 133.5(\mathrm{CH})$, $141.2(\mathrm{C}), 153.1(\mathrm{C}), 156.1(\mathrm{C})$; ESI-MS $(\mathrm{m} / \mathrm{z}) 223[\mathrm{M}+\mathrm{H}]^{+}$.

bpea (-)-19. Chloride (-)-18 (1.1 g, $2.65 \mathrm{mmol})$ was dissolved in a $\mathrm{CH}_{3} \mathrm{CN} / \mathrm{H}_{2} \mathrm{O}$ mixture 1:1 (5.4 mL). $\mathrm{Et}_{3} \mathrm{NH}_{2}$ (1.32 mmol, 0.2 $\mathrm{mL}$ of a $70 \%$ aqueous solution) was added dropwise to the first solution and the mixture stirred at $60{ }^{\circ} \mathrm{C}$. After $5 \mathrm{~min}, 10 \mathrm{M} \mathrm{NaOH}$ $(0.284 \mathrm{~mL}, 2.84 \mathrm{mmol})$ was added slowly. After being stirred for $1 \mathrm{~h}$ at $60^{\circ} \mathrm{C}$, the reaction was allowed to cool to $\mathrm{rt}$, the crude product was partitioned between $\mathrm{CHCl}_{3}$ and water, the organic layers were combined and dried with anhydrous $\mathrm{MgSO}_{4}$, and the solvent was removed under reduced pressure. The crude product was purified via flash chromatography on neutral alumina (40 g) with $\mathrm{CH}_{2} \mathrm{Cl}_{2}$ to give pure (-)-19 as a yellow oil (yield $0.52 \mathrm{~g}, 59 \%$ ): $[\alpha]_{\mathrm{D}}-96.2$ (c $1.1 \mathrm{CH}_{2} \mathrm{Cl}_{2}$ ); IR $v 2926 \mathrm{~s}, 1583 \mathrm{w}, 1550 \mathrm{~m}, 1463 \mathrm{~s}, 1360 \mathrm{~s}$, $1067 \mathrm{~s} \mathrm{~cm}^{-1} ;{ }^{1} \mathrm{H}$ NMR $\left(200 \mathrm{MHz}, \mathrm{CDCl}_{3}\right) \delta 0.62(\mathrm{~s}, 6 \mathrm{H}), 1.10(\mathrm{t}$, $J=7.2 \mathrm{~Hz}, 3 \mathrm{H}), 1.25(\mathrm{~d}, J=9.5 \mathrm{~Hz}, 1 \mathrm{H}), 1.39(\mathrm{~s}, 6 \mathrm{H}), 2.35(\mathrm{~m}$, $2 \mathrm{H}), 2.68(\mathrm{~m}, 6 \mathrm{H}), 3.07(\mathrm{~d}, J=3.0 \mathrm{~Hz}, 4 \mathrm{H}), 3.81(\mathrm{~s}, 4 \mathrm{H}), 7.15(\mathrm{~d}$, $J=7.6 \mathrm{~Hz}, 2 \mathrm{H}), 7.26(\mathrm{~d}, J=6.9 \mathrm{~Hz}, 2 \mathrm{H}) ;{ }^{13} \mathrm{C} \mathrm{NMR}(50 \mathrm{MHz}$, $\left.\mathrm{CDCl}_{3}\right) \delta 12.0\left(\mathrm{CH}_{3}\right), 21.2\left(\mathrm{CH}_{3}\right), 26.0\left(\mathrm{CH}_{3}\right), 32.0\left(\mathrm{CH}_{2}\right), 36.5$ $\left(\mathrm{CH}_{2}\right), 39.4(\mathrm{C}), 40.2(\mathrm{CH}), 46.2(\mathrm{CH}), 48.2\left(\mathrm{CH}_{2}\right), 60.0\left(\mathrm{CH}_{2}\right)$, $118.9(\mathrm{CH}), 133.3(\mathrm{CH}), 139.6(\mathrm{C}), 155.7(\mathrm{C}), 157.1$ (C); ESI-MS $(\mathrm{m} / \mathrm{z}) 416[\mathrm{M}+\mathrm{H}]^{+}$. Anal. Calcd for $\mathrm{C}_{28} \mathrm{H}_{37} \mathrm{~N}_{3}$ (415.61): C, 80.92; H, 8.97; N, 10.11. Found: C, 80.63; H, 9.28 ; N, 9.89.

[Mn( $\left.\left.\mathbf{B r}_{2}\right)((-)-19)\right],(-)-20$. Manganese(II) dibromide (0.010 g, $0.046 \mathrm{mmol})$ was dissolved in $\mathrm{CH}_{3} \mathrm{CN}(1 \mathrm{~mL})$, and a solution of (-)-19 (0.020 g, $0.046 \mathrm{mmol})$ in $\mathrm{CH}_{3} \mathrm{CN}(1 \mathrm{~mL})$ was added. The mixture stirred for $1 \mathrm{~h}$ at room temperature. After the addition of $1 \mathrm{~mL}$ of $\mathrm{Et}_{2} \mathrm{O}$, a white precipitate was formed. This precipitate was filtered, washed with a small amount of cold acetonitrile, and dried under vacuum (yield $0.016 \mathrm{~g}, 55 \%$ ): IR $v 2919 \mathrm{~m}, 1594 \mathrm{w}, 1450$ m, $1371 \mathrm{w}, 1118 \mathrm{~s}, 1031 \mathrm{~s} \mathrm{~cm}^{-1}$; ESI-MS $(\mathrm{m} / z) 551[\mathrm{M}-\mathrm{Br}]^{+}$. Anal. Calcd for $\mathrm{MnC}_{28} \mathrm{H}_{37} \mathrm{~N}_{3} \mathrm{Br}_{2}$ (630.4): C, 53.35; H, 5.92; N, 6.70. Found: C, 53.1; H, 6.23; N, 6.48 .

$[\mathbf{R u C l}((-)-10)(\mathbf{b p y})]\left(\mathbf{B F}_{4}\right),(-)-21$. A sample of $(-)-\mathbf{1 0}(55 \mathrm{mg}$, $0.099 \mathrm{mmol}$ ) was added to a $50 \mathrm{~mL}$ round bottomed flask containing a solution of $\mathrm{RuCl}_{3} \cdot 2 \mathrm{H}_{2} \mathrm{O}(24.2 \mathrm{mg}, 0.099 \mathrm{mmol})$ in dry EtOH, and the mixture was heated at reflux for $2.5 \mathrm{~h}$. The hot solution was filtered off in a frit, the volume was reduced in a rotary evaporator, and water $(2 \mathrm{~mL})$ was added upon which a green precipitate appeared. A $60 \mathrm{mg}$ sample of the solid obtained in this manner was added to a $25 \mathrm{~mL}$ round-bottomed flask containing a solution of $\mathrm{LiCl}(8 \mathrm{mg}, 0.263 \mathrm{mmol})$ in $\mathrm{EtOH} / \mathrm{H}_{2} \mathrm{O}(3: 1)(12 \mathrm{~mL})$, under magnetic stirring. Then, $\mathrm{NEt}_{3}(0.023 \mathrm{~mL})$ was added and the reaction mixture stirred at room temperature for $30 \mathrm{~min}$, at which point bpy (12 $\mathrm{mg}, 0.077 \mathrm{mmol})$ was added and the resulting mixture 
heated at reflux for $1 \mathrm{~h}$. The hot solution was filtered off in a frit and the volume reduced to dryness in a rotary evaporator under reduced pressure after the addition of an aqueous saturated solution of $\mathrm{NaBF}_{4}(1.5 \mathrm{~mL})$. A brown-red dust was obtained which was filtered in a frit, washed with $\mathrm{Et}_{2} \mathrm{O}$, and dried under vacuum: yield $43 \%$ (40 mg, $0.043 \mathrm{mmol}) ;{ }^{1} \mathrm{H}$ NMR $\left(500 \mathrm{MHz}, \mathrm{CDCl}_{3}, 25^{\circ} \mathrm{C}\right) \delta$ $=0.37 \mathrm{ppm}(\mathrm{s}, 3 \mathrm{H}, \mathrm{H} 91 \mathrm{a}-\mathrm{c}), 0.61(\mathrm{~s}, 3 \mathrm{H}, \mathrm{H} 80 \mathrm{a}-\mathrm{c}), 0.77(\mathrm{~s}, 3 \mathrm{H}$, H66a-c), 0.95 (m, 1H, H86a), 1.21 (s, 3H, H92a-c), 1.24 (m, 1H, H61a), 1.38 (m, 1H, H47a), 1.39 (s, 3H, H79a-c), 1.46 (s, 3H, H67ac), $2.20(\mathrm{~m}, 1 \mathrm{H}, \mathrm{H} 85 \mathrm{a}), 2.25\left(\mathrm{t},{ }^{3} J_{87 \mathrm{a}-86 \mathrm{a}}={ }^{3} J_{87 \mathrm{a}-86 \mathrm{~b}}=7.7 \mathrm{~Hz}, 1 \mathrm{H}\right.$, H87a), 2.39 (m, 2H, H60a, H73a), 2.69 (m, 1H, H61b), 2.82 (m, $1 \mathrm{H}, \mathrm{H} 74 \mathrm{~b}), 2.90\left(\mathrm{t},{ }^{3} J_{62 \mathrm{a}-61 \mathrm{a}}={ }^{3} J_{62 \mathrm{a}-61 \mathrm{~b}}=6.3 \mathrm{~Hz}, 1 \mathrm{H}, \mathrm{H} 62 \mathrm{a}\right), 2.97-$ 2.99 (m, 2H, H75a, H84), 3.17 (d, ${ }^{3} J_{72 \mathrm{ab}-73 \mathrm{a}}=15.2 \mathrm{~Hz}, 2 \mathrm{H}, \mathrm{H} 59 \mathrm{a}-$ b, H72a-b), 4.11 (s, 3H, H93a-c), 6.20 (s, 1H, H89a), 7.36-7.40 (m, 2H, H95a, H102a), 7.79 (s, 1H, H82a), 7.80 (s, 1H, H57a), 8.04-8.15 (m, 4H, H103a, H96a, H101a, H94a), 8.60 (dd, ${ }^{3} J_{97 a-96 a}$ $={ }^{3} J_{100 \mathrm{a}-101 \mathrm{a}}=1.8 \mathrm{~Hz} /{ }^{4} J_{97 \mathrm{a}-95 \mathrm{a}}={ }^{4} J_{100 \mathrm{a}-102 \mathrm{a}}=7.2 \mathrm{~Hz}, 2 \mathrm{H}, \mathrm{H} 97 \mathrm{a}$, H100a), 8.81 (s, 1H, H77a), 8.83 (s, 1H, H64a); ${ }^{13} \mathrm{C}$ NMR $\left(\mathrm{CDCl}_{3}\right): \delta=21.1$ (C91), 21.8 (C80, C66), 25.3 (C91), 25.8 (C79, C67), 31.1 (C86), 31.2 (C61), 31.6 (C74), 32.8 (C84), 33.2 (C59, C72), 38.0 (C78), 38.4 (C90), 39.0 (C65), 39.4 (C85), 39.7 (C60, C73), 43.5 (C87), 44.2 (C62, C75), 57.9 (C93), 88.9 (C88), 121.2 (C82), 121.4 (C57), 121.5 (C70), 124.1 (C100, C97), 125.3 (C95, C102), 136.5 (C96), 136.7 (C101), 148.0 (C89), 151.2 (C94, C103), 152.0 (C64), 152.2 (C77). ESI-MS $(\mathrm{m} / \mathrm{z}) 852.1\left[\mathrm{M}-\mathrm{BF}_{4}\right]^{+} ; E_{1 / 2}$ (V) $\left(\mathrm{CH}_{2} \mathrm{Cl}_{2}\right)=0.741 \mathrm{~V}$ vs SSCE. Elemental Anal. Calcd for $\mathrm{C}_{48} \mathrm{H}_{53} \mathrm{~N}_{5} \mathrm{O}_{1} \mathrm{RuClBF}_{4}$ : C, 58.57; N, 7.11; H, 5.94. Found: C, 58.25; N, 6.97; H, 6.33.

Catalytic Oxidation of Styrene. Experiments have been performed in $\mathrm{CH}_{2} \mathrm{Cl}_{2}$ dried over $\mathrm{CaH}_{2}$ at rt. In a typical run, ruthenium catalyst $(0.002 \mathrm{mmol})$, alkene $(0.2 \mathrm{mmol})$, and $\mathrm{PhI}(\mathrm{OAc})_{2}(0.4$ mmol) were stirred at room temperature in dichloromethane $(2.5$ $\mathrm{mL}$ ). The end of the reaction was indicated by the disappearance of solid co-oxidant. After addition of an internal standard, an aliquot was taken for GC analysis. GC conditions for the analysis of the oxidized products were as follows: initial temperature $80{ }^{\circ} \mathrm{C}$ for $25 \mathrm{~min}$, ramp rate $10 \% \mathrm{~min}$, final temperature $220{ }^{\circ} \mathrm{C}$, injection temperature $220{ }^{\circ} \mathrm{C}$, detector temperature $250{ }^{\circ} \mathrm{C}$, carrier gas $\mathrm{He}$ at $25 \mathrm{~mL} / \mathrm{min}$. All catalytic oxidations were carried out under nitrogen atmosphere.

Acknowledgment. This research has been financed by the MCYT of Spain (Project No. BQU2003-02884, CTQ200615634, and CSD2006-0003) and by CIRIT from Catalonia through SGR2001-UG-291. X.S. is grateful for the award of a doctoral grant from the University of Girona (UdG). A. Roglans from $\mathrm{UdG}$ is thanked for helpful discussions. A.v.Z. thanks the Swiss National Science Foundation for financial support.

Supporting Information Available: CIF file for complex (-)20, ${ }^{1} \mathrm{H}$ and ${ }^{13} \mathrm{C}$ NMR spectra of the final ligands and intermediates, $1 \mathrm{D}$ and 2D NMR spectra of complex $(-)-21$, and further experimental information. This material is available free of charge via the Internet at http://pubs.acs.org. The supplementary crystallographic data for this paper (CCDC 606513) can also be obtained free of charge via www.ccdc.cam.ac.uk/retrieving.html (or from the Cambridge Crystallographic Data Centre, 12, Union Road, Cambridge CB2 1EZ, U.K.; fax +44, 1223336033 or e-mail deposit@ccdc.cam.ac.uk).

JO0612372 